DOE/ERA-0041

Economic Analysis

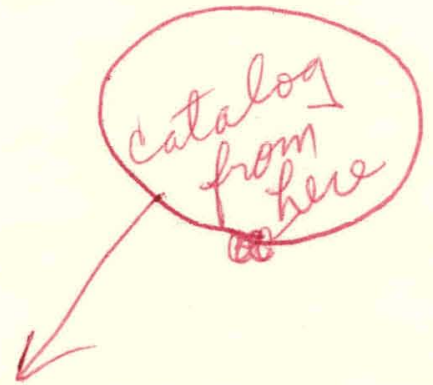

\title{
Standby Conservation Plan No. 1: Emergency Weekend Gasoline Sales Restrictions.
}

February 1979

U.S. Department of Energy

Economic Regulatory Administration

Office of Regulations and Emergency Planning

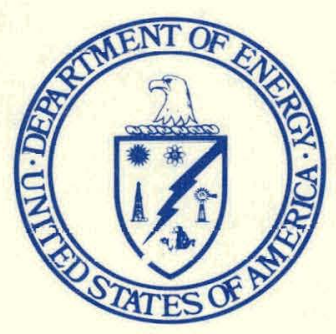




\section{DISCLAIMER}

This report was prepared as an account of work sponsored by an agency of the United States Government. Neither the United States Government nor any agency Thereof, nor any of their employees, makes any warranty, express or implied, or assumes any legal liability or responsibility for the accuracy, completeness, or usefulness of any information, apparatus, product, or process disclosed, or represents that its use would not infringe privately owned rights. Reference herein to any specific commercial product, process, or service by trade name, trademark, manufacturer, or otherwise does not necessarily constitute or imply its endorsement, recommendation, or favoring by the United States Government or any agency thereof. The views and opinions of authors expressed herein do not necessarily state or reflect those of the United States Government or any agency thereof. 


\section{DISCLAIMER}

Portions of this document may be illegible in electronic image products. Images are produced from the best available original document. 
Available from:

National Technical Information Service (NTIS) U.S. Department of Commerce

5285 Port Rnyal Rnad

Springfield, Virginia 22161

Price: Printed copy: \$5.25

Microfiche: $\$ 3.00$ 


\section{Economic Analysis}

\section{Standby Conservation Plan - Emergency Weekend Gasoline Sales Restrictions}

February $19 \overline{9} 9$

$$
\begin{aligned}
& \text { This report was prepared as an account of work } \\
& \text { sponsored by the United States Government. Neither the } \\
& \text { United States nor the United States Department of } \\
& \text { Energy, nor any of their employees, nor any of their } \\
& \text { contractors, subcontractors, or their employees, makes } \\
& \text { any warranty, express or implied, or assumes any legal } \\
& \text { liability or responsibility for the accuracy, completeness } \\
& \text { or usefulness of any information, apparatus, product or } \\
& \text { process disclosed, or represents that Its use wuuld nit } \\
& \text { infringe privately owned rights. }
\end{aligned}
$$

\section{U.S. Department of Energy}

Economic Regulatory Administration

Office of Regulations and Emergency Planning

Washington, D.C.

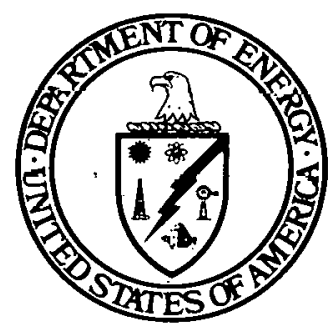




\section{SUMMARY}

\section{PURPOSE}

The Emergency Weekend Gasoline Sales Restrictions Plan was developed pursuant to the Energy Policy and Conservation Act (P.L. 94-163) for use in the event of a petroleum supply interruption or to satisfy the obligations of the United States under the International Energy Program. The purpose of this report is to identify and analyze, to the extent practicable, the potential economic impacts of the plan.

\section{DESCRIPTION OF PLAN}

The Emergency Weekend Gasoline Sales Restrictions Plan has been designed to conserve gasoline and diesel fuel normally used for social and recreational purposes. The plan would authorize the Secretary of Energy to impose restrictions on the retail sale of motor fuels during weekend hours, defined as Friday noon to sunday midnight. Only. certain types of commercial vehicles and emergency vehicles could purchase fuel during these hours.

The implementation of the measure is examined relative to a baseline economy characterized by a 15 percent petroleum shortfall. It is estimated that the measure would save 246,000 barrels per day of motor fuels, principally gasoline. Because the saved fuel can be made available to other sectors of the economy that are less petroleum intensive, it is 
projected that GNP would rise by approximately $\$ 7$ billion as a result of the measure. The impact of the measure would vary sharply from one sector of the economy to another, however, with some industries experiencing losses in revenue.

The cost of imposing the measure is preliminarily estimated at $\$ 5.2$ million for nine months. 


\section{TABLE OF CONTENTS}

$\underline{\text { Page }}$

SUMMARY

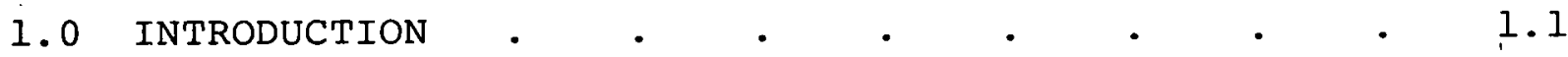

1. 1 PURPOSE OF THIS STUDY $\quad . \quad \ldots \quad \ldots \quad$. $\quad . \quad$. 1.1

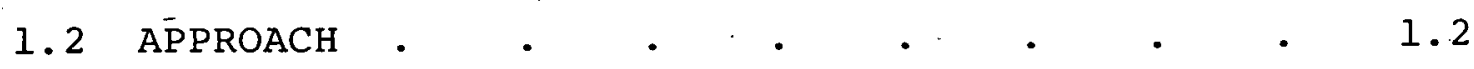

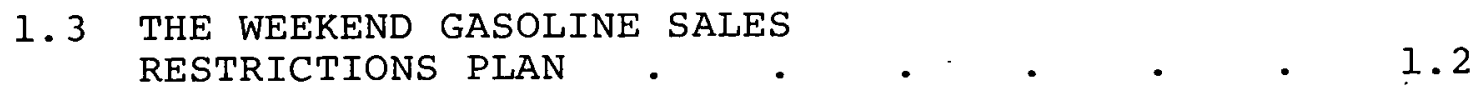

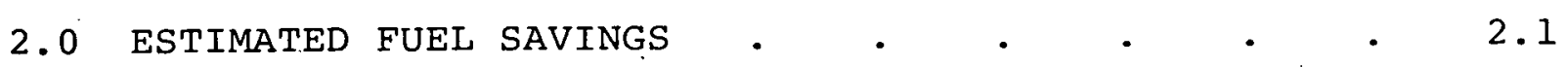

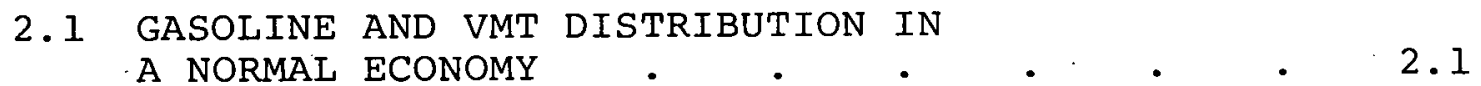

2.2 CHANGES IN DRIVING PATTERNS $\quad . \quad \ldots \quad$. $\quad . \quad 2.4$

2.3 HOUSEHOLD GASOLINE CONSUMPTION
WITH A FUEL SHORTFALL . . . . . . . . $\quad 2.6$

2.4 GASOLINE DEMAND REDUCTIONS UNDER
THE WEEKEND GASOLINE RESTRICTIONS $\quad$ • . $\quad$ • $\quad 2.8$

2.4.1 Automobile Fuel Consumption . . . $\quad 2.8$

2.4 .2 Pleasure Boats $\quad . \quad \ldots \quad$. $\quad . \quad$. $\quad 2.11$

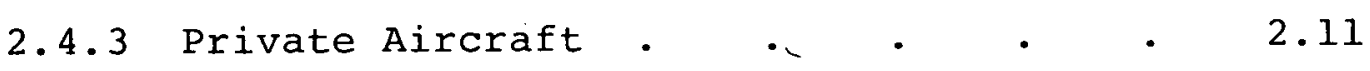

2.4.4 Summary of Total Potential Reduction - 2.12

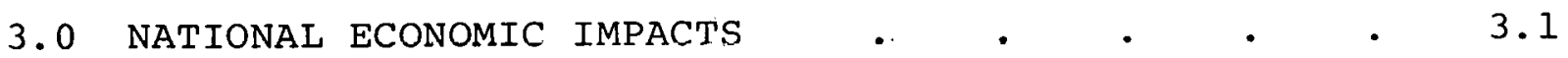

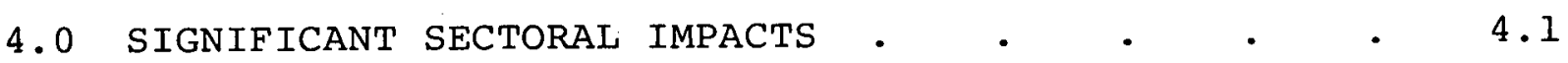

4.1 IMPACTS OF A SUPPLY INTERRUPTION
ON INDIVIDUAL SECTORS $\quad . \quad . \quad . \quad . \quad 4.1$

4.1 .1 inferenće 1 . $1.0 \quad$. $\quad . \quad$. 4.2

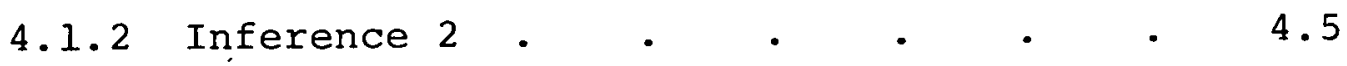

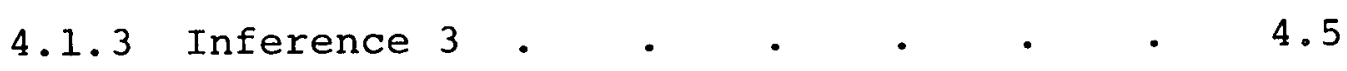

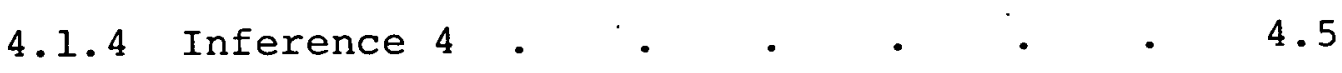


4.2 INCREMENTAL IMPACTS OF THE WEEKEND

GASOLINE SALES RESTRICTIONS PLAN

ON THE "TRAVEL" INDUSTRY

4.2.1 Impacts on Commercial

Lodging Industry $\quad . \quad . \quad . \quad \cdot 4.7$

4.2.2 Impact on the Restaurant Industry . . 4.9

4.2.3 Recreation and Entertainment. $\because \because . \quad . \quad 4.10$

4.2.4 Incidental Travcl Expenditures .. . 4.17

4.2.3 Transportation Kélated Studies . . 4.18

4.3 TRAVEL-RELATED DURABLE GOODS . . . . 4.20

4.3.1 Automotive Sales . . . . . . 4.20

4.3.2 Reçreational Vehicles . . . . 4.21

4.3.3 Pleasure Boats . . . . . . 4.22

4.3.4 Impact on Sales of Private Aircraft . 4.23

4.3.5 Summary of Affected Industries . . 4.23

4.3 .6 Offsetting Gains . . . . . . 4.25

5.0 PROJECTED STATE AND REGIONAL IMPACTS . . . 5.1

5.1 PROJECTED IMPACTS OF A 1980-1981

SUPPLY INTERRUPTION •

5.1.1 Regional Manufacturing Employment . 5.1

5.2 INCREMENTAL STATE AND REGIONAL

IMPACTS OF THE WEEKEND SALES

RESTRICTIONS PLAN

5.2.1 Impacts on State Motor Fuel,
Automotive and Highway Use Receipts . 5.6

5.2.2 State and Regional Economic Impacts . 5.6

6.0 FEDERAL COSTS . $. \quad . \quad . \quad . \quad . \quad . \quad . \quad . \quad 6.1$ 
APPENDIX A: DETAILED CALCULATIONS OF MAJOR INDUSTRY IMPACTS

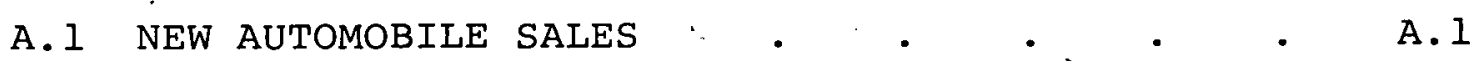

A. 2 IMPACTS ON HOTEL-MOTEL INDUSTRY . $\quad$. . . A.2

A. 3 IMPACT ON CAMPGROUNDS AND

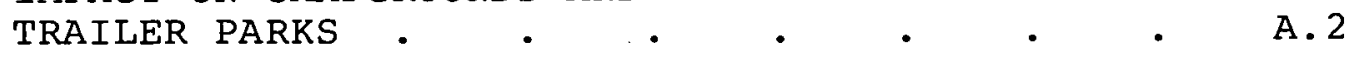

A. 4 IMPACT ON RESTAURANT INDUSTRY . . . . . . A.3

A. 5 IMPACT ON EXPENDITURES FOR
ENTERTAINMENT AND INCIDENTALS . . . . . A. 4 
2.1 Distribution of Household VMT by Trip

Page

Purpose and Day of the Week 1980-1981

Normal Economy (Billions of ,VMT)

2.2

2.2 Distribution of Household Gasoline

Consumption by Trip Purpose and Day

of the Week 1980-1981 Normal.

Economy (Billions of Gallons) . . . . . . 2.2

2.3 Computation of Market Clearing Price

for Gasoline in a 20 Percent Shortfall

(per gallon)

2.4 Distribution of Household VMT by Trip

Purpose and Day of the Week 1980-1981

Interrupted Economy (Billions of VMT)

2.5 Distribution of Household Gasoline

Consumption by Trip Purpose and

Day of the Week 1980-1981 Interrupted

Economy (Billions of Gallons).

2.6 Household Automobile Gasoline Demand

Rēđüctiōn trom Weekend Sales

Restrictions. (Billions of Gallons

per Year)

4.1 Most Affected Industries as Estimated by Various Embargo Studies
4. by Various Emargo studies

4.2 Summary of Embargo Studies . . . . . . . . 4.4

4.31972 Amusement Industry Revenues . . . . . 4.16

4.4 Revenue Losses of Affected Industries as the Result of Restriction of Weekend Casoline Distribution .

5.1 Manufacturing and Nonagricultural Employment by Region, 5-Quarter Embargo Average (1980-1981) (Thousands of People)

5.2 Relative Importance of TravelGenerated Tax Revenues 


\subsection{INTRODUCTION}

1.1 PURPOSE OF THIS STUDY

The Weekend Gasoline Sales Restrictions Plan, developed pursuant to the Energy Policy and Conservation Act (Public. Law 94-163), is intended to be implemented in the event of a petroleum supply interruption or to satisfy the obligations of the United States under the International Energy Program: The principal purpose of this study is to identify and evaluate the economic impacts of the plan in accordance with Section 201(f) of EPCA. Section 201(f) specifies that the conservation plan shall, to the extent practicable, be accompanied by an evaluation of the potential economic impacts of the plan, including analysis of:

1. any effects of the plan on

(a) vital industrial sectors of the economy,

(b) employment (on a national and regional basis),

(c) the economic vitality of states and regional areas,

(d) the availability and price of consumer goods and services,

(e) the gross national product; and

2. any potential anticompetitive effects. 


\subsection{APPROACH}

The fuel savings resulting from the plan and the economic impacts of the plan are both estimated relative to a baseline characterized by the U.S. economy in 1980-81, experiencing a hypothesized 15 percent interruption in the availability of petroleum. It is assumed that petroleum allocation and price controls are in effect and that, because of shifts in the refinery mix, the shortfall amounts to 20 percent for gasoline and correspondingly less for other petroleum products. The study makes a sharp distinction between the effects of the shortfall and of implementing the weekend restrictions measure.

If the plan were to be implemented in a less severe petroleum shortfall, the fuel savings would be substantially greater but the economic impacts would be less favorable.

\subsection{THE WEEKEND GASOLINE SALES RESTRICTIONS PLAN}

The purpose of the weekend gasoline sales distribution restrictions plan is to significantly reduce the consumption of fuel for discretionary purposes without severely restricting commerce or necessary health and safety activities. To carry out this objective, retail gasoline outlets, including those that sell marine fuel and aviation gasoline, will be authorized to distribute gasoline and diespel fuel only to certain types of commercial and emergency vehicles during the weekend hours specified by the Department of Energy (DOE). 
During the weekend hours between Friday noon and sunday midnight, retail filling station operators would be authorized to sell diesel fuel to all trucks. They could also sell gasoline to single unit and combination trucks which have (1) six tires or more and for (2) a gross vehicle weight rating of at lieast 10,000 pounds." Other vehicles for which gasoline and diesel fuel could be distributed are:

- emergency vehicles,

- vehicles which are registered as common carriers with the ICC or which are certified pursuant to ICC regulations,

- taxicabs, limousines, buses and other commercial passenger carriers for hire,

- commercial marine craft,

- heavy construction and farm equipment,

- emergency utility vehicles; and

- emergency production vehicies. 
STANDBY ENERGY CONSERVATION

PLAN NO. 1

EMERGENCY WEEKEND GASOLINE SALES RESTRICTIONS

ECONOMIC ANALYSIS

February 1979

U.S. Department of Energy

Economic Regulatory Administration

Office of Regulations and Emergency Planni.ng Washington, D.C. 
This chapter provides estimates of the savings in highway fuel, marine fuel, and aviation gasoline that would be obtained from implementing the weekend restrictions on sales of gasoline and diesel fuel. Most of the savings is obtained from the anticipated cutback in highway driving and virtually all of this is motor gasoline. Only one percent of the highway motor fuel projected to be saved is diesel fuel. For ease of exposition, therefore, this report uses the term "gasoline" to include all motor fuel for highway use.

\subsection{GASOLINE AND VMT DISTRIBUTION IN A NORMAL ECONOMY}

Exhibit 2.1 shows a breakdown of vehicle miles traveled (VMT) in a normal 1981 economy. The 1981 total of approximately 1.3 trillion vehicle miles was taken from a current study being prepared by Jack Faucett Associates for the DOE. The pattern of vehicle miles is assumed to be the same as that in the last Nationwide Personal Transportation Study (NPTS) conducted in 1969-1970. These percentages, by purpose and day of the week, are relative to total vehicle miles and are shown in parentheses. The breakdowns of vehicle miles by length of trip within the social and recreational category are more uncertain. Data from both the NPTS and the National Travel survey relating to the distribution of trips by mileage intervals were used as starting points. 
EXHIBIT 2.1 Distribution of Household VMT by Trip Purpose and Day of the Week 1980-1981 Normal Economy Billions of VMT

Earning a Living

Subtotal

Family Business.

Educational, Civic and Religious.

Subtotal

Social, Recreational and other:

Subtocal

Irip Length $0 \rightarrow 99$

(one-way)
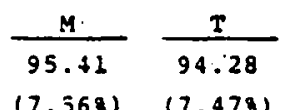

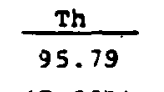

$(7.388)$

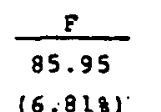

$\frac{\text { Sat }}{35.09}$

(2.788)
41.27
43.42
$\$ 3.29$
$+8.59$
45.31
47.9
35.72
305.6
$(.3 .278)$
(3.448).
(3.438)
(3.858)
$(3.598)$
(3.808)
$(2.838)$
$(24.23)$

Source: U.S. Departnene of Transportation Federal Highway Administration, Nationwide Fersonal iransportation Study Report No. 19. 1974. See Appendix B.

Exhibit 2.2 shows the corresponding distribution of gasoline consumption. A 1981 projected mile-per-person figure of 16.5 is used to derive a control total of 76.5 billion gallons. Automobiles used for trips in excess of 100 miles would ordinarily obtain better gasoline mileage. Therefore, these trips were assumed to achieve a 25 percent increase in fuei economy. 
EXHIBIT 2.2 Distribution of Household Gasoline Consumption by Trip Purpose and Day of the Week 1980-1981 Normal Economy (Billions of Gallons)

\begin{tabular}{|c|c|c|c|c|c|c|c|c|c|}
\hline & & $\mathbf{M}$ & $T$ & $\boldsymbol{w}$ & Th & $F$ & Sat & Sun. & Total \\
\hline $\begin{array}{l}\text { Earning a Livi } \\
\text { Subtotal }\end{array}$ & وר & $\begin{array}{l}5.96 \\
(7.798)\end{array}$ & $\begin{array}{c}5.89 \\
(7.708)\end{array}$ & $\begin{array}{l}5.82 \\
(7.6 .28)\end{array}$ & $\begin{array}{l}5.99 \\
(7.838)\end{array}$ & $\begin{array}{c}5.37 \\
(7.028)\end{array}$ & $\begin{array}{c}2.19 \\
(2.868)\end{array}$ & $\begin{array}{c}1.02 \\
(1.338)\end{array}$ & $\begin{array}{l}32.2 \\
(42.18)\end{array}$ \\
\hline $\begin{array}{l}\text { Family Busines } \\
\text { Educational, } \\
\text { and Religious } \\
\text { Subtotal }\end{array}$ & ivic & $\begin{array}{l}2.58 \\
(3.378)\end{array}$ & $\begin{array}{l}2.71 \\
(3.548)\end{array}$ & $\begin{array}{l}2.71 \\
(3.548)\end{array}$ & $\begin{array}{l}3.04 \\
(3.978)\end{array}$ & $\begin{array}{l}2.83 \\
(3.708)\end{array}$ & $\begin{array}{l}3.00 \\
(3.928)\end{array}$ & $\begin{array}{l}2.23 \\
(2.928)\end{array}$ & $\begin{array}{l}29.1 \\
(25.08)\end{array}$ \\
\hline $\begin{array}{l}\text { Social, Recre } \\
\text { and Other: }\end{array}$ & & & & & & & & & \\
\hline Subtotal & & $\begin{array}{c}2.82 \\
(2.388)\end{array}$ & $\begin{array}{c}2.24 \\
(2.938)\end{array}$ & $\begin{array}{c}1.90 \\
(2.488)\end{array}$ & $\begin{array}{l}2.15 \\
(2.818)\end{array}$ & $\begin{array}{c}3.33 \\
(4.358)\end{array}$ & $\begin{array}{c}6.38 \\
(8.348)\end{array}$ & $\begin{array}{l}7.35 \\
(9.618)\end{array}$ & $\begin{array}{l}25.2 \\
(32.98)\end{array}$ \\
\hline $\begin{array}{l}\text { Trip I.ength } \\
\text { (one-way) }\end{array}$ & $0-99$ & $\begin{array}{c}1.46 \\
(1.918)\end{array}$ & $\begin{array}{c}1.46 \\
(1.918)\end{array}$ & $\begin{array}{l}1.46 \\
(1.918)\end{array}$ & $\begin{array}{l}1.46 \\
(1.918)\end{array}$ & $\begin{array}{l}2.15 \\
(2.818)\end{array}$ & $\begin{array}{c}4.19 \\
(5.488)\end{array}$ & $\begin{array}{c}5.00 \\
(6.548)\end{array}$ & $\begin{array}{l}17.2 \\
(22.58)\end{array}$ \\
\hline & $100+$ & $\begin{array}{l}.36 \\
(.478)\end{array}$ & $\begin{array}{c}.78 \\
(1.028)\end{array}$ & $\begin{array}{c}.44 \\
(.578)\end{array}$ & $\begin{array}{l}.69 \\
(.908)\end{array}$ & $\begin{array}{l}1.18 \\
(1.548)\end{array}$ & $\begin{array}{l}2.19 \\
(2.868)\end{array}$ & $\begin{array}{c}2.35 \\
(3.078)\end{array}$ & $\begin{array}{c}8.0 \\
(10.48)\end{array}$ \\
\hline Total & & $\begin{array}{l}10.36 \\
(13.58)\end{array}$ & $\begin{array}{l}10.84 \\
(14.28)\end{array}$ & $\begin{array}{l}10.43 \\
(13.68)\end{array}$ & $\begin{array}{l}11.18 \\
(14.68)\end{array}$ & $\begin{array}{l}11.53 \\
(15.18)\end{array}$ & $\begin{array}{l}11.57 \\
(15.18)\end{array}$ & $\begin{array}{l}10.60 \\
(13: 98)\end{array}$ & $\begin{array}{c}76.5 \\
(200.08)\end{array}$ \\
\hline
\end{tabular}

Source: U.S. Department of Transportation Federal Highway Administration, Nationwide PersonaJ Transportation Study Report No. 19, 1974. See Appendix B. 
A supply interruption of petroleum will lead to a higher "price" for gasoline, either in terms of price at the pump or time spent in queues at retail gasoline stations. The higher price can be expected to cause consumers to reallocate their gasoline consumption to more highly valued uses.

Assume first that the price of gasoline is allowed to rise to its market clearing level. Exhibit 2.3 calculates the estimated market price of gasoline to be $\$ 1.75$ assuming a 20 percent shortage.

In computing the free market price, an assumed short-run demand elasticity of -0.15 is used. This estimate is consistent with a number of econometric studies that have been published

EXHIBIT 2.3 Computation of Market Clearing Price for Gasoline in a Shortfall (per gallon)

Assumed Quantities

E - Elasticity of Demand $-0.15$

$\frac{\Delta Q}{0}--$ Assumed \& Change in Consumption (a) $-208$

$P_{1}--$ Initial Pre-shortfall Price per Gallon
(1980 dollars) $\$ 0.75$

Unknown

$\mathrm{P}_{2}$-- Market Price per Gallon in the Absence of Price Controls Defined Relation

$E=\frac{\Delta Q}{Q} \div \frac{P_{2}-P_{2}}{P_{1}}$

$\underline{\text { Result }}$

$\mathbf{P}_{2}=\$ 1.75$

(a) Given a 15 pctroleum supply interruption, DOE has assumed that refineries would tend to lower their output of gasoline relative to other petroleum products. This would result in a $20 \%$ gasoline shortfall. 
in the last four years.

The -0.15 figure is treated as an arc elasticity rather than a point elasticity. That is, 0.15 is assumed to be the ratio of the percentage change in quantity to the percentage change in price for a single large change in the price or quantity.

There is little empirical information on demand elasticities for gasoline by various trip purposes. Howéver, most observers would agree that work trips show the least responsiveness to gasoline price changes in the short run. It is assumed, for illustrative purposes, that the price elasticity for work trips is one-third that for nonwork trips. Under such an assumption, gasoline consumed for social, recreational, and personal business trips falls by 28 percent in the hypothesized shortfall and fuel consumption for work trips falls by only nine percent.

In a situation where market prices are not allowed to rise, the allocation of gasoline between work and nonwork trips would be roughly the same. In this case, the "rationing" function would be performed primarily by waiting in lines at gasoline service stations rather than by a higher fuel price. However, some degree of black market activity would surely arise as some consumers would pay a higher effective price in the form of bribes, favors, and tied sales (gasoline sold at unpublicized

1. John Kraft and Mark Rodekohr, "Regional Demand for Gasoline; A Temporal Cross-Section and Specification," Journal of Regional Science, $18(1), 1978$. Page 53 of this article lists 10 recent studies of automobile gasoline demand. 
hours with purchases of, for example, batteries or tires). In any event, the money and implicit time costs per gallon would be an estimated $\$ 1.75$ per gallon in a 20 percent gasoline shortfall.

\subsection{HOUSEHOLD GASOLINE CONSUMPTION WITH A FUEL SHORTFALL}

The shortfall scenario breakdown of vehicle miles traveled (VMT) and gallons consumed are shown in Exhibits 2.4 and 2.5 respectively. The procedure used to obtain these results is the same as that described above. All categories of nonwork trips were reduced by the same percentaqe (27.9 percent). There is no empirical evidence to indicate which types of nonwork driving would be most likely cut back the most.

EXHIBIT 2.4 Distribution of Household VMT by Trip Purpose and Day of the Week 1980-1981 Interrupted Economy (Billions of VMT)

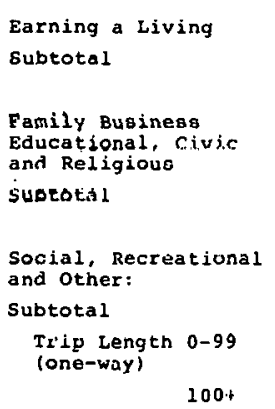

Total

\begin{tabular}{|c|c|c|c|c|c|c|c|}
\hline$-\ldots$ & $T$ & N & $\mathrm{I}^{\mathrm{H}} \mathrm{H}^{\mathrm{m}}$ & $F$ & sat & Sun & Total \\
\hline 86.56 & 85.44 & 84.48 & 86.84 & 77.92 & 31.84 & 14.88 & 468.0 \\
\hline$(8.578)$ & $(8.468)$ & $(8.378)$ & $(8.608)$ & $(7.728)$ & $(3.158)$ & $(1.478)$ & $(46.38)$ \\
\hline 29.76 & 31.36 & 31.36 & 35.04 & 32.64 & 34.72 & 25.76 & 220.6 \\
\hline$(2.958)$ & $(3.118)$ & $(3.118)$ & $(3.478)$ & $(3.238)$ & $(3.448)$ & $(2.558)$ & $(21.91)$ \\
\hline 24.99 & 30.68 & 25.70 & 29.46 & 41.28 & 78.85 & 90.14 & 321.1 \\
\hline$(2.478)$ & $(3.038)$ & $(2,548)$ & $(2.918)$ & $(4.098)$ & $\cdot(7.818)$ & $(8.938)$ & $(31.80)$ \\
\hline $\begin{array}{l}16.80 \\
(1.668)\end{array}$ & $\begin{array}{l}16.80 \\
(1.668)\end{array}$ & $\begin{array}{l}16.80 \\
(1.668)\end{array}$ & $\begin{array}{l}16.80 \\
(1.668)\end{array}$ & $\begin{array}{l}24.80 \\
(2.468)\end{array}$ & $\begin{array}{l}48.48 \\
(4.008)\end{array}$ & $\begin{array}{l}57.76 \\
(5.728)\end{array}$ & $\begin{array}{l}198.2 \\
(19.68)\end{array}$ \\
\hline 0.19 & 13.88 & 8.90 & 12.66 & 16.48 & 30.37 & 32.28 & 122.9 \\
\hline$(.818)$ & $(1.378)$ & $(.888)$ & $(1.258)$ & $(1.638)$ & $(3.018)$ & $(3.2 .219)$ & $(22,28)$ \\
\hline $\begin{array}{l}141.11 \\
(14.08)\end{array}$ & 147.48 & 141.54 & 151.58 & 151.84 & 145.41 & 130.78 & 1009.7 \\
\hline$(14.08)$ & $(14.68)$ & $(14.08)$ & $(15.08)$ & $(15.08)$ & $(34.48)$ & $(13.04)$ & $(100.00)$ \\
\hline
\end{tabular}

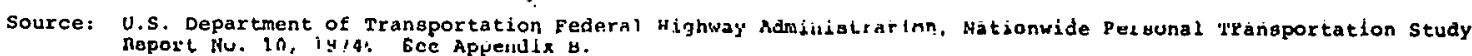


EXHIBIT 2.5 Distribution of Household Gasoline Consumption by Trip Purpose and Day of the Week 1980-1981 Interrupted Economy (Billions of Gallons)

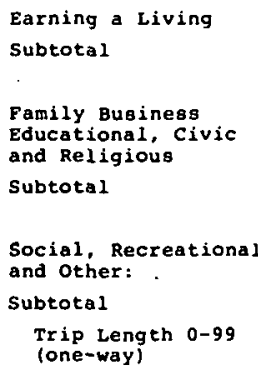

Total

\begin{tabular}{|c|c|c|c|c|c|c|c|}
\hline$M$ & T & $W$ & Th & $F$ & Sat & Sun & Tota1 \\
\hline 5.41 & 5.34 & 5.28 & 5.43 & 4.87 & 1.99 & .93 & 29.2 \\
\hline$(8.848)$ & $(8.738)$ & $(8.638)$ & $(8.878)$ & $(7.968)$ & $(3.258)$ & $(1.528)$ & $(47.88)$ \\
\hline 1.86 & 1.96 & 1.96 & 2.19 & 2.04 & 2.17 & 1.61 & 13.8 \\
\hline$(3.048)$ & $(3.208)$ & $(3.208)$ & $(3.588)$ & $(3.338)$ & $(3.558)$ & $(2.638)$ & $(22.58)$ \\
\hline 1.31 & 1.62 & 1.37 & 1.55 & 2.40 & 4.61 & 5.31 & 18.2 \\
\hline$(2.148)$ & $(2.658)$ & $(2.248)$ & $(2.538)$ & $(3.928)$ & $(7.538)$ & $(8.688)$ & $(29.78)$ \\
\hline $\begin{array}{l}1.05 \\
(1.728)\end{array}$ & $\begin{array}{l}1.05 \\
(1.728)\end{array}$ & $\begin{array}{l}1.05 \\
(1.728)\end{array}$ & $\begin{array}{l}1.05 \\
(1.728)\end{array}$ & $\begin{array}{l}1.55 \\
(2.538)\end{array}$ & $\begin{array}{l}3.03 \\
(4.958)\end{array}$ & $\begin{array}{c}3.61 \\
(5.908)\end{array}$ & $\begin{array}{l}12.4 \\
(20.38)\end{array}$ \\
\hline .26 & .57 & .32 & .50 & .85 & 1.58 & 1.70 & 9.4 \\
\hline$(.428)$ & $(.938)$ & $(.528)$ & $(.818)$ & $(1.398)$ & $(2.588)$ & $(2.788)$ & $(5.788)$ \\
\hline B. 58 & 8.92 & 8.61 & 9.17 & 9.31 & 8.77 & 7.85 & 61.2 \\
\hline$(14.08)$ & $(14.68)$ & $(14.18)$ & $(15.08)$ & $(15.28)$ & $(14.38)$ & $(12.88)$ & $(100.08)$ \\
\hline
\end{tabular}

Source: U.s. Department of Transportation Federal Highway Administration, Nationwide Personal Transportation Study Report No. 10, 1974. See Appendix $B$.

No mention, thus far, has been made of probable behavior on the part of retail gasoline station operators. In the 19731974 embargo, weekend travel was inhibited by the closure of the majority of stations on Saturdays and especially Sundays. In tourist areas, such behavior on the part of operators would probably diminish the longer the interruption continued. One would expert the market. to produce a variety of arrangements by which gasoline would at least be made available to some weekend travelers to recreational and tourist areas. Various sorts of arrangements were beginning to emerge toward the end of the 1974 embargo period and their reemergence in any future shortfall would,ilikely occur more rapidly.

2. Impact of the United States Energy Policy on the Tourism Industry, U.S. Department of Commerce, U.S. Travel Service, pp. 15-16, 1975. 
2.4 GASOLINE DEMAND REDUCTIONS UNDER THE WEEKEND GASOLINE RESTRRICTIONS

\subsubsection{Automobile Fuel Consumption}

A basic assumption in the present report is that nearly all weekend round trips for social and recreational purposes in excess of 300 miles would be eliminated as a result of the plan: 'Trips over 300 miles are generalìy oútside the rànge of a full tank of gas for most automobiles in the U.S. For trips less than 300 miles, it would be reasonable to expect that longer trips would be curtailed more than shorter trips. Most motorists would desire to maintain a precautionary reserve of fuel for essential purposes, including work, emergencies, etc. Uncertainty as to the availability of emergency repair services, such as changing of flat tires and towing, would also serve to discourage weekend driving. These considerations would become stronger in a motorist's decision-making process in relation to the length of the planned trip. The assumption in this report is that perhaps only 10 percent of driving on very short trips (less than 50 miles one-way) would be eliminated by the plan. Percentage reductions for trips between 50 and 150 miles are assumed. to increase in a linear fashion from 10 percent to 100 percent. All reductions are assumed to occur in the category of Social and Recreational Driving. 
Column (2) of Exhibit 2.6 summarizes the potential reductions relative to the shortfall scenario for trips of various lengths. The numbers in parentheses represent the percentage reductions that are assumed.

As a result of the plan, motorists are likely to shift both to trips on weekdays and to shorter trips. Assumed effects of these two offsetting factors are shown in columns (3) and (4) of Exhibit 2.6. It is difficult to estimate the tendency to shift social and recreational driving to weekdays. It is unlikely that the VMT shift would be greater than 20 percent, without significant time away from jobs.

EXHIBIT 2.6 Household Automobile Gasoline Demand Reduction from Weekend Sales Restrictions (Billions of Gallons per Year) (1)

\begin{tabular}{|c|c|c|c|c|c|}
\hline $\begin{array}{c}\text { Trip } \\
\text { Length } \\
\text { (One-Way) }\end{array}$ & $\begin{array}{l}\text { (1) } \\
\text { Social Recreational } \\
\text { Waekend Gasoline } \\
\text { Congumption- } \\
\text { Interrupted Economy }\end{array}$ & $\begin{array}{c}\text { (2) } \\
\text { Gross } \\
\text { Impact (2) }\end{array}$ & $\begin{array}{c}\text { (3) } \\
\text { Weekday } \\
\text { offget (3) }\end{array}$ & $\begin{array}{c}(1) \\
\operatorname{Trip} \\
\operatorname{Orfset}(4)\end{array}$ & $\begin{array}{c}\text { (5) } \\
\text { Net } \\
\text { Raduction (5) }\end{array}$ \\
\hline $0-19$ & 3.378 & $=-{ }_{\text {(iov) }}^{338}$ & +.068 & & -.270 \\
\hline $20-49$ & 2.781 & - (iov) & +.056 & . & -.223 \\
\hline $50-9.9$ & 2.001 & $\begin{array}{l}-.667 \\
(-32.53)\end{array}$ & +.130 & +.347 & -.173 \\
\hline $100-149$ & 1.004 & $\begin{array}{l}-778 \\
(-77.51)\end{array}$ & +.156 & $\$ 2,49$ & -.373 \\
\hline $150-299$ & 1.646 & $\begin{array}{l}-1.646 \\
(-1000)\end{array}$ & +.329 & +.299 & -1.018 \\
\hline $300+$ & $1.199^{\circ}$ & $\begin{array}{c}-1.199 \\
(-10001)\end{array}$ & +.300 & +.122 & 1.077 \\
\hline Tula 1 & 18.319 & $=\frac{3.130}{142.11)}$ & 1.033 & 1.019 & -9:294 \\
\hline \multicolumn{6}{|c|}{ 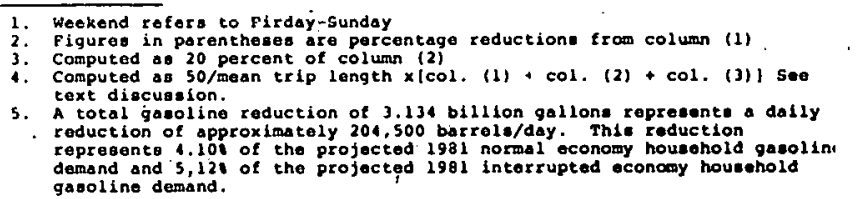 } \\
\hline
\end{tabular}


Recreational pursuits that could not be accomplished by weekday trips, might be accommodated by shorter weekend trips. For the present study, it is assumed that every weekend trip, 50 miles or longer, not shifted to a weekday (i.e., 80 percent of such trips), is replaced by a trip of roughiy 50 miles. For instance, if the average (unshifted) trip within the 100 to $150 \mathrm{mile}$ category is $125 \mathrm{miles,} \mathrm{then} \mathrm{an} \mathrm{offsetting}$ trip within this category is assumed to be 50 miles.

Column (5) shows the net impact of the measure for each trip length interval. The total demand reduction is 3.1 billion gallons per year, or 204,000 barrels per day ( 1 bbl = 42 gallons of gasolinc).

In the first few months of the interruption, it would not be surprising to find the majority of trips over 300 miles eliminated. If half of all trips over 300 miles were eliminated as a result of the shortfall and a full 20 percent of the. curtailed weekend driving were shifted to weekdays, the daily demand reduction from the weekend restrictions would be only an additional 141,000 barrels per day. This figure. would seem to be a reasonable lower limit of the impact of the plan on personal gasoline consumption. On the other hand, if weekend driving were cut back only 25 percent in the interrupted economy, and there were no shifting of curtailed weekend driving to weekdays, then the demand reduction resulting from the measure might be as high as 271,000 barrels per day. 
It is estimated that 2.5 billion gallons of marine fuel will be consumed by pleasure boats in the 1981 normal economy. In a 20 percent petroleum shortfall, it is assumed that boat owners would reduce their marine fuel consumption by 20 percent.

It is estimated that 75 percent of marine fuel is consumed on weekends.' Although the measure prohibits purchases of marine fuel on weekends, it does not pronibit consumption. The majority of outings would be unaffected since they could use fuel purchased prior to the weekend. As a rough estimate, it is assumed that the measure would eliminate one-third of boating fuel consumption.

The estimate of demand reduction potential was derived as follows:

3. Marine fuel is defined here as actual marine fuel and gasoline used for boating purposes. This projection for marine fuel consumption comes from a 1977 Coast Guard survey of marine fuel consumption. U.S. Coast Guard, Recreational Boating in the Continental U.S. in 1973 and 1976: The Nationwide Boating Survey, 1978. Figures for pleasure boat gasoline consumption are available for 1976 and 1973. Boats in circulation figures are available for 1973, 1976 and 1980. Therefore, 1981 figures for gasoline consumption are based on the annual growth rate in boats in circulation. Because the marine fuel consumption figure provided by the Coast Guard is relatively high compared to other estimates, our figure represents a compromise between those of the Coast Guard and others. 
2.5 billion gallons of marine fuel or 59.5 million barrels of marine fuel are projected to be consumed by pleasure boats in the 1981 normal economy. It is anticipated that a 20 percent gasoline shortfall will reduce marine fuel consumption by 20 percent. Therefore, 2.0 billion gallons of marine fuel or 47.6 million barrels of marine fuel are projected to be consumed by pleasure boats in the 1981 interrupted economy. It is anticipated that 75 percent or 35.7 million barrels of marine fuel will be consumed on weekends in the 1981 interrupted economy. Divided by 365 days per year, this equates to 98,000 barrels per day. Assuming that the measure would eliminate one-third of marine fuel consumption, the potential demand reduction is approximately 33,000 barrels per day. Reflecting the uncertainty in the estimates of marine fuel consumption, "low". and "high" estimates for the reductions are 25,000 barrels per day and 40,000 barrels per day, respectively.

\subsubsection{Private Aircraft}

It is anticipated that a petroleum supply interruption will cause a 20 percent reduction in aviation gasoline consumption. The weekend consumption of aviation gas by private aircraft is estimated at 18,300 barrels per day in 
(4)

the 1981 interrupted economy, assuming that 50 percent of flying is done on weekends. The potential for demand reduction is decreased somewhat by the fact that some pleasure flying could be shifted to weekdays. A more realistic assessment of the demand reduction potential, therefore, is about one-half of total weekend consumption.

The estimate of demand reduction potential was derived as follows:

Approximately 563 million gallons of fuel are projected to be consumed by private aircraft in the 1981 interrupted economy. This equates to 13.4 million gallons annually. Fifty percent or 6.7 million gallons are expected to be consumed on weekends. Dividing by 365 days per year and converting to barrels, total weekend consumption equals approximately 18,000 barrels per day. The increased flying on weekdays is expected to decrease potential demand reduction by about 50 percent. The most likely potential demand reduction, therefore, is estimated at 9,000 barrels per day.

\subsubsection{Summary of Total Potential Reduction}

The summary of potential demand reductions in thousands of barrels per day induced by the measure is shown below:

4. DOT, FAA, Aviation Forecasts, Fiscal Years 1979-1990, September 1978, p. 62 . 
Low "Most Probable" High

(1) Household Travel

141

204

271

(2) Pleasure Boating

$$
25
$$

33

40

(3) Private Aircraft

$\underline{5}$ TOTAL

171

9

14

327

The low and high figures for category (3) were derived by multiplying the weekday offset with factors of 0,50 and 1.50. The ranges for reductions in household automobile travel and boating were discussed in Sections 2.4 .1 and 2.4.2. 


\subsection{NATIONAL ECONOMIC IMPACTS}

The imposition of weekend restrictions on gasoline and diesel fuel will have adverse impacts on those industries that are, directly affected by the reductions in weekend driving and in the use of pleasure boats and private aircraft. These impacts are discussed in Chapter 4.

Offsetting these adverse impacts, there will be a positive economic impact resulting from the use of the conserved fuel. Because the curtailed activities tend to be highly petroleum intensive, diverting fuel for use in other sectors of the economy, at a time when petroleum is in very short supply, will permit an expansion in those industries that are most critically constrained by the petroleum shortage. This will ease production bottlenecks, thereby permitting other sectors to expand. The net effect will be an increase in economic activity. Thus, although there will be some economic setbacks in some sectors, the economy as a whole will benefit.

The precise magnitude of the economic stimulus depends on how the saved fuel is distributed among industries. A rough approximation of the gains can be obtained through the use of a response function. 
A GNP response function has been developed by SAI.

This analysis projects that GNP loss increases at a constant percentage rate from the first barrels of shortfall. If conservation efforts were made prior to a'supply shortfall, the response function probably would be roughly linear instead of consisting of two segments. However, at a 15 percent shortfall, the difference between these two forms of response functions are negligible in relationship to the overall uncertainty associated with projections of this type. The GNP response function indicates that, with a 15 percent shortfall of petroleum, increasing the supply of petroleum by an incremental 1,000 barrels per day leads to an increase in GNP of approximately $\$ 16$ million. Accordingly, the weekend restrictions, by saving an estimated 246,000 harrels per day, can be expected to increase GNP by an estimated $\$ 16$ billion. After subtracting the $\$ 9$ billion loss projected to result directly from the weekend restrictions (discussed in Chapter 4 ), there is a net GNP gain of $\$ 7$ billion. Corresponding to this rise in GNP there is likely to be a small increase in employment.

1. Science Applications, Inc. Integrated Economic Impact Assessment of Petroleum Supply Interruption Contingency Actions (October 1977). 


\subsection{SIGNIFICANT SECTORAL IMPACTS}

This chapter describes the impact of the Weekend Gasoline Sales Restrictions Plan on various sectors of the economy. After reviewing those sectors that would be most impacted by a petroleum supply interruption, the incremental impact of the Weekend Gasoline Sales Restrictions Plan on this interrupted economy is discussed.

\subsection{IMPACTS OF A SUPPLY INTERRUPTION ON INDIVIDUAL SECTORS}

An analysis of the overall impact of a petroleum shortfall on economic activity is best done with macroeconomic models, such as those used in existing studies of petroleum supply interruptions, either based upon the 1973-1974 embargo or upon projections concerning some possible future shortfall.

1. A partial list of these studies includes:

- FEA Study: Report to Congress on the Economic Impact of Energy Actions, Federal Energy Administration, May 1976;

- George Perry Study: Higher Oil Prices and the World Economy, Chapter 2 - The United States, Edward Fried and Charles Schultze, editors, The Brookings Institute, 1975;

- SAI Study: Integrated Economic Impact Assessment of Petroleum Supply Interruption Contingency Actions, Science Applications, Inc., October 1977;

- EPRCP Study: Report on the Feasibility of Developing an Emergency Percentage Reduction Contingency Plan for Petroleum, June 1977;

- DRI Study: "The Potential Economic Impact of a 1980 OPEC Oil Embargo," from The Data Resources U.S. Long-Term Review, Fall 1977. 
These studies differ in many respects: they refer to shortfalls occuring during different time frames, they assume different types of shortfalls, they use different types of models, and they consider different allocation programs or no allocation program at all. For detailed comparison of the outputs of these studies it would be necessary to analyze the structure, assumptions, and constraints of each model used. Without attempting such an exterded analysis, it is still possible to draw certain interences from these studies lased upon the conclusions or areas of agreement common to all. The following four inferences are the most significant.

\section{4.i.1 Interence 1}

A major effect of a petroleum supply interruption will be to create a depressed economic condition. Because of lags that affect economic impacts, this depression may not begin until after the beginning of the supply interruption, and may continue after the interruption has ended. This decline in the economy will most affect industries that are sensitive to economic downturns, such as construction and durable equipment. Industries heavily dependent upon petroleum, such as transportation industries, will also be particularly affected. The industries listed as being most affected by a supply interruption are shown in Exhibit 4.1, 
. EXHIBIT 4.1 Most Affected Industries as Estimated by Various Embargo Studies (a) . A . .

\section{Always Mentioned}

- Motor Vehicles and Parts

- Residential Construction

\section{Almost Always Mentioned}

- Other Transportation Equipment, such as

- Aircraft and Parts

- Railroad Equipment

- Transportation Services

- Nonresidential Construction

- Other Durable Goods, such as

- Basic Metals

- Various Metal Products

- Various Types of Machinery

- Stone, Clay, and Glass

- Rubber and Plastics

a. These sectors are identified in the six studies referred to in this section.

The most affected industries will experience a percentage declire equal to about 2.5 to 5 times the percentage decline in gross national product. The average factor from all the studies is approximately 3. Assuming a GNP decline in a supply interruption of approximately six percent, this implies that the most affected industries will decline by approximately 18 percent. Because of the effects described earlier in this chapter, specific industries:may suffer more or less than would otherwise be predicted. Exhibit 4.2 shows the information on which this estimate is based. 
(B)

Average Shortfall

Affected

Industries (8)

$27^{(c)}$
(A)

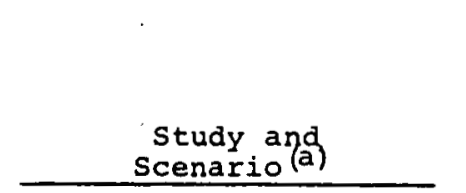

FEA

Study and
Scenariola

Perry

FRB model

MLchigan model

Battelle

SAI

No allocation

EPAA allocation plan

RPA allocation plan

9.5

31.4

5.6

16.1

$12^{(c)}$

$2 ?$

EPAA allocation plan

DRI

3.2

4.8

1.9

$--$

PRP allocation plan

EPRCP

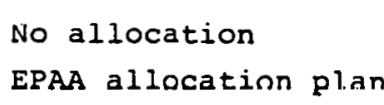

11 (c)
Nature of to Size of Most Affected
Industries

3.3

Transportaion, Contruction, Durables

$-$

Automobiles, Construction
4.4
27.1
6.1

Transportation, Durable Equipment, Construction

Same plus Mobile Homes \& Textile Products

Same - plus Mobile Homes

$30.2^{(c)}$

2.9

Same as F.PAA
2. .5.

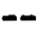

4.8
Transportation, Durable Equipment, conseruceion

Transportation, Construction, Durable Manufactures

a. These studies are cited in detail in the text.

b. Some of the statistics in this column are for a single quarter of the $1973=75$ reference period. Exhibit 4.3 in Chapter 4 shows averages' for the four quarters of 1974 .

c. Estimate. 
4.1 .2 Inference 2

The majority of the nation's industries will be affected at about the same rate as GNP. These include many manufacturers and a number of consumer services and products.

\subsubsection{Inference 3}

Most of the studies predict that consumer goods industries will be affected least. Specifically mentioned are such areas as leather goods, tobacco, and food products. These least affected industries are usually assumed to suffer no more than $1 / 2$ to $2 / 3$ the percentage decline in GNP.

\subsubsection{Inference 4}

All of the studies agree that investment and durable goods industries will be relatively harder hit than consumption goods industries, although the estimated difference in impact varies greatly from study to study.

As noted previously, the discussion of impacts in this section has referred to petroleum supply interruption impacts, with allocation and price control programs assumed in effect. The following section discusses the effects on industrial sectors which would result from implementing the proposed gasoline restrictions prograll. 


RESTRICTIONS PLAN ON THE "TRAVEL" INDUSTRY

A variety of industries dependent on weekend automobile travel are expected to be impacted by weekend gasoline sales restrictions. Examples are commercial lodging, restaurants, boating, and entertainment. The projected magnitudes of adverse impacts on these industries depend on assumptions regarding the extent to which weekend trips are curtailed and how the fuel saved from these trips is used. In addition to the service industries that would be affected by the measure, several consumer durable goods industries would be affected. Sales of automobiles, recreational vehicles, boats and private aircraft would be expected to decline, but the quantitative estimates of these impacts are highly uncertain.

It is expected the Weekend Gasoline Sales Restrictions Plan would sharply curtail weekend auto travel over 300 miles. The plan will also substantially reduce trips of shorter length since individuals will seek to maintain precautionary. reserves of gasoline in their tanks. The exact impact of the plan on miles traveled and losses to affected industries will also depend on the extent to which individuals substitute a shorter weekend trip for a lengthy one and weekday travel for weekend. For example, weekday travel in extended vacations may be substituted for weekend travel of substantial distances. In addition, some businesses might be expected to shift work schedules toward weekends allowing workers to have days off 
in midweek. While many industries would be severely affected by an elimination of all weekend travel, the shifting to. shorter trips and to weekday travel serves to mitigate the impact.

\subsubsection{Impacts on Commercial Lodging Industry}

\section{Hotels and Motels}

The total drop in person-nights spent in indoor commercial lodging due to the proposed restrictions is estimated at 92.7. million person-nights per year.

rate of $\$ 15$ per person-night, this implies annual gross revenue losses to the industry of $\$ 1,391$ million or 10.5 percent of estimated gross 1981 revenues.

Rather than being spread evenly across the entire lodging industry, the brunt of the reductions would be borne by lodging establishments. concentrated geographically along major interstate highways and in resort/recreation areas, for which weekend lodgers constitute a much larger proportion of the total business.

2. See Appendix A for detailed calculations of the impacts. These figures assume an offset in weekend losses due to substitution toward weekday and shorter trips. With no offset, the losses are $\$ 1,855$ million.

3. 1978 U.S. Industrial Outlook, U.S. Department of Commerce, U.S. Government Printing Office, p. 455, 1978. 
In extreme cases during the 1973-1974. limitations on Sunday gas sales, motels along the major interstates and primary highways reported weekend occupancy as low as three to five percent of normal levels.

It is difficult to separate the incremental impacts of a Weekend Gasoline.Sales Restrictions Plan from the petroleum shortfall itself. However, in an industry that in 1976 employed over a million full- and part-time workers, a proportional cutback in employment would mean some 100,000 additional unemployed.

\section{Campgroünds, 'I'railer Parks, Etc.}

The net drop in person-nights spent in outdoor commercial accommodations such as campgrounds, trailer parks, etc., due to the proposed restrictions is estimated at 79 million personnights per year. Assuming an average fee of $\$ 1.50$ per personnight, this implies annual gross revenue losses to the industry of $\$ 119$ million. (4)

As in the case of conventional hotel/motel lodgings, it is difficult to assess the potential impact of the measure on employment in campgrounds, trailer parks, etc. Many of these outdoor facilities tend to be run by tamilies, which would be reluctant to discharge employees.

4. See Appendix A, part 3. 


\subsubsection{Impact on the Restaurant Industry}

The reduction in weekend driving is estimated to cost the restaurant industry approximately $\$ 3.7$ billion in revenues. This figure is obtained by estimating the gross reduction in sales of meals resulting from reductions in weekend driving and correcting for the substitution of shorter trips for displaced long weekend trips. In addition, the reduction in weekend travel will not prevent individuals from patronizing local restaurants so that restaurant meals formerly taken on weekend trips may be transferred to local restaurants. A complete derivation of the revenue loss estimate is shown in Appendix A.

However, the figure for the reduction in restaurant revenues can be misleading. The impact will be uneven with certainly some large net losers and probably some gainers. Restaurants that cater to weekend travel or recreation areas will undoubtedly experience substantial losses. Restaurants near populated areas could actually gain from the diverted travel the plan encourages.

The ratio of the increase in sales between 1974 and 1977 to the increase in employment implies a one employee addition for each $\$ 22,000$ in sales. Using a sales decline of $\$ 3.1$ billion translates to an employment reduction of about 140,000; 
this is approximately five percent of total restaurant (5)

employment.

\subsubsection{Recreation and Entertainment}

Tourist expeñditures for recreation and entertainment while on weekend automobile trips are estimated to have been about

$\$ 2$ billion in 1976 .

After taking into account the possible offsets due to shorter weekend and weekday trips, expenditures by tourists on these services are expected lo decline by about $\$ 1$ billion in a 1981 economy.

The National Travel Expenditure Survey does not provide an expenditure breakdown of the individual amusement industries associated with weekend auto travel. Given this lack of information, the approach taken is to identify those industries that are likely to be most affected by the measure and to qualitatively discuss the potential impacts.

5. Data from the U.S. Industrial Outlook -- 1978, U.S. Department of Commerce, Washington, D.C., pp. 187-188, 1978. The relationship is one employee for $\$ 22,000$ - in sales revenues.

6. U.S. Travel Data Service, 1976 National Travel Expenditure Survey. 


\section{Winter Sports}

The skiing industry, a $\$ 2$ to $\$ 2.5$ billion industry, was among the recreation industries hardest hit by the 1973-1974 supply interruption and limits on Sundày gas sales. It is expected any future supply interruption would have a similar crippling effect. The additional impact of the Weekend Gasoline Sales Restrictions Plan could be severe since two-thirds of all skiing is done on weekends. be regained by an increase in weekday skiing or longer stays at ski resorts.

Among ski resort owners, Vermont operators reported that weekend skiing was down by 35 percent in early 1974, and this figure probably was not atypical of other New England ski areas, which depend on the weekend auto trade from the mid-Atlantic States. Interestingly, ski vacations of a week or more in duration did not suffer noticeably, indicating that the decline in weekend skiing was indeed largely due to the sunday gas limitations and attendant uncertainty about gas availability, rather than poor snow conditions or the general economic decline.

7. Booz, Allen and Hamilton, Inc., "Sensitivity of the Leisure-Recreational Industry to the Energy Crisis," prepared for the Federal Energy Office, January 18, 1974. Appendix "Skiing." 
In the East, ski. areas in upstate New York and Pennsylvania, which are located closer to major population centers than the New England ski resorts, presumably suffered smaller weekend. losses, and may even have been partly compensated by the diversion of some regular New England skiers, although capacity at these resorts is limited. Midwestern ski areas for the most part display a similar regional character, and hence, probably suffered less of a decline than New England. Although precise data are not available, it is estimated that the Mid-Atlantic and Midwestern ski areas suffered losses of up to 15 percent of: their normal business.

Some of the Western ski resorts--in California, Colorado, New Mexico, etc.--draw a greater proportion of their clientele from relatively distant parts of the country. Skiers at these resorts as a group are wealthier, more likely to arrive by plane and stay, for periods longer than a single weekend than their counterparts in other parts of the country. on the uther hand, many of the Western ski areas are located 50 to 150 miles from the populated metropolitan areas. Weekend trips by local residents to these ski resorts would be significantly impacted. Snowmobiling, unlike skiing, does not appear to have been severely affected by the ban, since the machines themselves use relatively little fuel, and for the most part, their owners employ them relatively close to home. 


\section{Water Sports - Boating}

The boating industry would be negatively affected by the measure since Saturday and/or Sunday sales of both gasoline and marine fuel would be restricted. Approximately 75 percent of all boating is on weekends, and most boat owners must drive cars either to reach their craft or to trailer-haul their boats to water. However, according to one study, the average boat owner drives about 50 miles per'week to use his boat, well within the normal driving radius of one full tank of gas. (8) more distant waters also have the option in most cases of traveling instead to nearer waters. Conceptually, then; the restrictions on auto gas sales would appear to have little direct impact on recreational boating.

Far more serious, from the standpoint of boat owners, vendors and manufacturers, is the problem posed by restricted weekend sales of marine fuel. Use of large inboard and highpowered outboard craft. with their relatively high fuel consumption would be more severely affected by a sunday-only restriction than small outboards, due to the latter's greater cruising range on a tank of fuel. The all-weekend restrictionshould cut back significantly on all forms of weekend boat use.

8. Booz, Allen and Hamilton, Inc., Op. Cit. 
For the fuel reductions estimated in Chapter 2, it was assumed that total demand would be cut by one-third. It is not known to what extent weekend boaters, like skiers, would shift boating activity away from the weekend boating toward the longer vacations. Marina operators, exclusive of those with marine sales franchises, should not be affected severely since, for boats kept in the water, marina fees and maintenance requirements remain relatively constant. Lost revenues on fuel sales would depend on the magnitude of the shortfall to marine fuel dealers, and the extent to which boat owners chouse and wuuld be able to fill their tanks during the week in anticipation of the weekend unavailability of fuel.

\section{Outdoor sports - Hunting and Fishing}

Total annual revenues in manufacturing and other industries catering to hunters and fishermen have been estimated at up to $\$ 7$ billion annually, accounting for employment in the vicinity of 30,000 workers. According to one study, approximately 95 percent of all hunting and fishing related travel is by auto, but the average number of vehicle miles traveled is only 23 miles per trip. (9) on hunting and fishing manufacturers and outfitters 1 s unl1kely

9. Booz, Allen and Hamilton; Inc. : Op. Cit., Appendix "Hunting and Fishing." 
to be severe, especially since hunters and fishermen traveling long distances are likely to shift toward locations closer to home. Conversely, remote areas whose economies depend heavily on expenditures by out-of-area hunters and fishermen, particularly in the West, would probably be significantly affected.

\section{Park Use}

In terms of park use, there would presumably be less use of the national parks and recreation areas concentrated in the West, which cater almost exclusively to auto travelers. There would be increased use of local, state and regional parks closer to home. The direct impact of such a trend on park revenues would be insignificant, since direct tourist revenues to all Federal parks (admissions, fees, etc.) were only \$17.2. million (10)

in 1975 . However, the indirect effect of such a trend on local economies that are dependent on Federal park generated tourist expenditures for food, accommodations and-incidentals would probably be severe.

Miscellaneous Leisure - Recreation Industries

This category includes most leisure and recreation industries not covered in the discussion up to this point.

10. U.S. Bureau of the Census, Statistical Abstract of the U.S.: 1976 (97th Edition), Table 351, p. 214 . 
The main exclusion from this category is motion pictures which probably would not be seriously affected. The main subcategories, together with 1972 receipts, are listed in Exhibit 4.3.

\section{EXHIBIT 4.3 1972 Amusement Industry Revenues}

Recreation and Amusement Industry

Producers, Orchestras, Entertainers Bowling Alleýs, Billiards, Pools

Dance Halls, Studios, Schools (a)

Baseball, Football Clubs, etc..

Promotors (a)

Racetrack Operation (a)

Public Golf Course (a)

Skating Rinks (a)

Amusement Parks (a)

Coin-Operated Amusement Devices (a)

Concession Operators, Amusement

Dcvicco, Rider(a)

Carnivals, Circuses, Fairs (a)

Other (a)

Total
1972 Receipts (Million $\$$ )

1436

1204

95

504

1079

270

95

492

312

120

168

2830

$\overline{8635}(\mathrm{~b})$

\footnotetext{
(a) Estimated

(b) Totals may not add due to independent rounding. SOURCE: Statistical Abstract of the U.S., p. 787, 1975.
} 
Of course, certain subcategories are more likely to be seriously affected by the measure than others, inasmuch as some are more auto dependent than others. Race track operators would be more seriously affected than baseball, football and other commercial sports, since the former are more likely to be located well outside major population centers and tend to draw customers from a relatively wide geographical area. Similar observations pertain to amusement areas, concessionaries, carnivals, circuses and other subcategories including aquariums, boat and canoe rentals, art galleries and museums. Some of these categories could be unaffected or even gain from shifts away from long weekend trips.

\subsubsection{Incidental Travel Expenditures}

In addition to expenditures for lodging, food, and entertainment, automobile travelers also purchase a variety of other goods on trips. These purchases include medicine, cosmetics, clothing, personal services, and services. The Weekend Gasoline Sales Restrictions Plan would mainly affect only the geographic distribution of these sales; most of these items would be purchased regardless of whether the trip were taken or not. Of course, on the other hand, some items, such as souvenirs, suntan lotion, etc., would only be purchased if a trip were taken. 
The 1976 National Travel Expenditure indicated that weekend automobile travelers spend for incidentals about $\$ 4.00$ per person per day (after conversion to 1977 dollars). It is assumed. that 20 percent of these expenditures would be foregone if the Weekend Gasoline Sales Restrictions Plan were implemented. On the basis that approximately 490 million person-days (see Appendix A) on trips would be eliminated under the measure, the drop in expenditure for travel-related incidentals is $\$ 400$ million.

\subsubsection{Transportation-Related Sectors}

\section{Service station Sales}

It is assumed that service stations would be able to sell their entire gasoline allocation in spite of the weekend ban on gas sales, and inasmuch as stations would be permitted to remain open (but not sell gasoline other than to commercial and emergency vehicles) on weekends, the measure would not directly lead to large unemployment in the reldil gasolino sales sector. An obvious concern is that with the proposed measure's prohibition of gasoline sales to most vehicles, there are incentives for only a very few stations to remain open during weekends. Accordingly, it may be difficult for emergency vehicles to obtain fuel. There dppears no administrntively easy method by which DOE can ensure that a minimal number of slations remain open for this purpose. Programs to have some service stations open (on perhaps a rotating basis) can be most 
efficiently set up by local authorities or by local retail service station associations. .

\section{Public Transport}

It is questionable to what extent auto travelers in the 300 to 600 mile range, mainly affected by the plan, would find the airlines a practicable alternative to the auto, inasmuch as only two percent of all person-trips in this category were made by air in 1974 . means of transport in this shorter-range category. This con-. clusion is strengthened by the results of a 1974 opinion research study that found that respondents taking trips of 100 to 499 miles preferred the auto over planes by more than a 2-to-1 margin. (12)

1974 gasoline shortage on their weekend travel plans, only one to two percent of the respondents noted an inclination to fly more instead of driving.

$$
\text { (13) }
$$

11. Nationa1 Travel Survcy, Table 4, p. 46 and l'able 1, p. 34 .

12. Opinion Research Corp., "Impact of the Energy Shortage on U.S. Travel Habits," conducted for U.S. Travel Data Center, p. 288 .

13. Ibid, p. 261. 
Other mass transport modes (bus and rail), while enjoying somewhat greater favor as alternatives to the auto for purposes of weekend travel, apparently do not have sufficient equipment to handle a large percentage of weekend auto trips.

\subsection{TRAVEL-RELATED DURABLE GOODS}

In addition to impacts on the travel industry, the measure is expected to influence the sales of consumer durable goods related to weekend recreation. The largest impacts are expected to be on the sales of automobiles, recreational vehicles, boats and private aircraft. Predicting sales of consumer durables is always very uncertain even in a normal economy. The uncertainties are even greater in a situation with no historical precedent. If consumers. view the measure as being implemented indefinitely, the impacts would likely be greater than a measure viewed as lasting a short time.

\subsubsection{Automotive Sales}

The Weekend Gasoline Sales Restrictions Plan could reinforce the impact of the shortfall. on retail automotive sales. The predicted level of 1981 motor vehicles and parts expenditures is $\$ 99$ billion, (15) auto sales.

14. Booz, Allen and Hamilton, Inc., Op. Cit., p. 17. 15. Data Resources, Ine., The Data Resources U.S. Long Term Review, Fall 1976 and using the ratio of new auto sales to total vehicles and parts from the U.S. Bureau of the Census, Statistical Abstract of the United States: 19.76 (97th Edition), Washington, D.C., p. 791 . 
It is plausible to assume that auto sales will decline by approximately $1-1 / 2$ percent as a result of the measure; or about $\$ 900$ million.

The plan will encourage the purchase of certain types of automobiles relative to others. In order to offset the effects of the weekend restrictions on gasoline sales, consumers will shift purchases toward automobiles with a larger mileage range per gas tank.

\subsubsection{Recreational Vehicles}

The recreational vehicle (RV) industry is one of the ferw recreation and leisure industries for which considerable data from the 1973-1974 crisis are available, presumably because it was one of the hardest and most directly hit. Sales of motor homes, travel trailers, camping trailers, truck campers and pickup covers were about 40 percent lower in 1974 and 1973 . Sales of recreational vehicles in 1980-1981 are projected to be $\$ 5.4$ billion in 1977 dollars. (17) reduction in sales due to the shortfall, such as occurred in

16. U.S. Bureau of the Census, Statistical Abstract of the United States: 1976 (97th Edition), p. 599, Table 999.

17. Recreation Vehicle Industry Association, Facts and Trends 1977 , p. 5,1978 . 
1973-1974, and a' 25 percent reduction due to the measure, the estimated impact on recreational vehicles is $\$ 800$ million. The 25 percent decline is based on an equivalent reduction in all weekend social and recreational driving.

\subsubsection{Pleasure Boats}

To the extent it is assumed that new boat sales are reflected in existing ownership patterns, 31 percent of new boat unit sales are sailboats (with or without auxiliary iilboard power) and presumably would be little affected by the measure. Thus, approximately 70 percent of all boat units sold are in categories directly affected by the fuel sales plan; this implies a reduction in boat sales of $\$ 720$ million due to the measure. (18)

percentage of reduced sales would be simply postponed until the termination of the measure.

18. Annual sales of boats are estimated to be $\$ 4$ billion. A 15 percent petroleum shortfali is expected to reduce sales by 20 percent to $\$ 3.2$ billion. 'l'he percentage reduclion in sales due to the measure is assumed to be approximately the percentage of boating done on weekends times the percentage reduction in weekend use of boats. As discussed in Section 2.4.2, these percentages are 0.75 and 0.33 , respectively. This implies a 25 percent reductiun in sales or approximately $\$ 700$ million. 
4.3.4 Impact on Sales of Private Aircraft

In 1977 domestic retail sales of single-engine civilian aircraft, the category which includes most privately flown aircraft, was approximately 13,800 units valued at an estimated $\$ 483$ million. (19)

component of the gasoline sales measure assume 50 percent of all private flying is done on weekends. If it is assumed that the plan would likewise reduce demand for private aircraft by 50 percent, the aircraft industry would face retail sales losses estimated at $\$ 250$ million per year.

\subsubsection{Summary of Affected Industries}

Exhibit 4.4 provides an appraisal of revenue losses for impacted industries. The total revenue loss to impacted industries is over $\$ 9$ billion dollars. These losses are distributed unevenly both across industries and within the impacted industries. For example, the hotel/motel industry experiences large revenue iosses from the weekend plan, but within the industry selected hotels and motels may gain while others near resorts or the tourist centers may be forced to close.

19. U.S. Industrial Outlook 1978, gives total 1977 factory shipments of 17,500 units, from which 3,700 was deducted for export sales. Based 'on figures in General Aviation Manufacturers Association, General Aviation Aircraft Fleet Directory 1976, average retail sales price of this type of aireraft is estimated to be $\$ 35,000$. 
EXHIBIT 4.4 Revenue Losses of Affected Industries as the Result of Restriction. of Weekend Gasoline Distribution

$1980-1981$

Affected Industries

Automobiles. (Millions \$)

Recreation Vehicles 900

Boats 800

Private Aircraft 700

Hotels/Motels 250

Campgrounds, Trailer Parks 1390

Restaurants 120

Recreation and Entertainment 3680

Travel-Related Incidentals 1050 400 Total

There are a variety of sources of uncertainty and error surrounding the figures for revenue losses. These include:

1. The degree of response of affected industries toward attracting and retaining sales cannot be predicted. The 1973-1974 embargo led to a multitude of marketing tactics tried by individual producers to counteract the reduction in demand for their products. Many producers introduced rebates to persuade consumers to purehage now rather than wait. Many hotels and motels provided packages that included gasoline for return trips. It is not clear if the present plan 
will allow heavily impacted resorts or areas to make similar offers.

2. Firms and individuals will have an incentive to offer work schedules that allow employees to have nonwork days in the middle of the week. If this behavior becomes widespread, considerably more shifting to. weekday travel may occur than is anticipated.

3. The short term emergency nature of the plan implies many of the impacts will occur because purchases are postponed rather than eliminated. The period following the plan and oil shortfall may find many consumers buying. the postponed articles. This behavior could apply to trips as well as durable purchases. 'Saving up vacation time or postponing weekend travel may result in abnormally high travel-related expenditures. following the measure's termination.

For these reasons, the $\$ 9$ billion estimated revenue loss would appear to represent a worst-case scenario.

\subsubsection{Offsetting Gains}

The losses discussed above will be offset by a gain of approximately $\$ 16$ billion (discussed in Chapter 3) resulting from the use of the fuel saved by the weekend restrictions. There will consequently be a net gain to the economy of approximately $\$ 7$ billion. 
Some of the \$l6 billion gain will go to the industries discussed in this chapter, reducing the adverse impacts that they realize. Part of the gain will go to other economic sectors. Precisely how the gain is distributed depends on how the saved fuel is used. It seems likely that the industries most severely impacted by the shortfall will be the ones that tend to gain most from implementing the measure. 


\subsection{PROJECTED IMPACTS OF A 1980-I981 SUPPLY INTERRUPTION}

This chapter discusses the State and regional impacts of the Weekend Gasoline Sales Restrictions Plan measure. To begin, a quick review of the state and regional impacts of the hypothetical 15 percent shortfall is provided. The impacts were analyzed for regional manufacturing employment, and travel-related employment. Differences in impacts on regional productivity for rural and urban areas were also examined.

Because the standby allocation program would use a period immediately before the interruption as a base period, any regional imbalances induced by the allocation program itself during a future supply interruption would almost certainly be smaller than those during the 1973-1974 embargo. Also, greater administrative experience: with the allocation regulations should lead to a better balance of supply. Depending on the nature and severity of the interruption, however, some imbalances probably would result. Such imbalances would produce productivity losses in the gasoline-deficient states and regions.

\subsubsection{Regional Manufacturing Employment}

One recent study ${ }^{(1)}$ has projected manufacturing and nonagricultural employment levels for five quarters in 1980-1981 under each of three scenarios.

- No petroleum shortfall.

- A four million barrel por day petruleum shortfall without mandatory allocation or price controls.

- A four miliion barrel per day petroleum shortfall with mandatory allocation and price controls.

1. Science Applications, Inc., Integrated Economic'Impact Assessment of Petroleum Supply Interruption Contingency Actions, October 1977. 
The results, presented in Exhibit 5.1, are similar to FEA's estimation of the employment effects of the 1973-1974 (2)

embargo. States on the East Coast, particularly in the Northeast, would be adversely affected, as would states in the South and in the Midwest.

2. Fuderal Energy Administratinn, Report to Congress on the Economic Impact of Energy Activities, May 1976. 
MANUFACTURING.

\begin{tabular}{|c|c|c|c|c|c|}
\hline Region (*) & $\begin{array}{c}\text { NNo } \\
\text { Petroleum } \\
\text { Shortfall } \\
\end{array}$ & $\begin{array}{c}\mathrm{B} \\
4 \mathrm{MM} / \mathrm{D} \\
\text { Petroleum } \\
\text { Shortfall } \\
\text { Without } \\
\text { Mandatory } \\
\text { Allocation } \\
\end{array}$ & $\begin{array}{c}\mathrm{C} \\
\mathbf{M} \overline{\mathrm{M}} / \mathrm{D} \\
\text { Petroleum } \\
\text { Shortfall } \\
\text { With } \\
\text { Mandatory } \\
\text { Allocation }\end{array}$ & $\frac{\mathrm{C}-\mathrm{A}}{\mathrm{A}}$ & $\begin{array}{c}. y \\
\frac{C-B}{B} \\
\end{array}$ \\
\hline 1 & $1,464.1$ & $1,393.5$. & $1,317.5$ & -10.08 & -5.58 \\
\hline 2 & $2,218.0$ & $2,095.7$ & $1,942.5$ & -12.58 & -7.38 \\
\hline 31 & $2,278.0$ & $2,163.6$ & 2.020 .8 & -11.38 & -6.68 \\
\hline 4 & $3,812.9$ & $3,648.6$ & $3,369.1$ & -11.68 & -7.78 \\
\hline 5 & $5,614.9$ & $5,322.4$ & $5,030.4$ &.-10.48 & -5.58 \\
\hline 6 & $1,742.1$ & $1,673.7$ & $1,596.6$ & -8.38 & -4.68 \\
\hline 7 & $1,060.0$ & $1,009.6$ & 967.7 & -8.78 & -4.18 \\
\hline 8 & 360.2 & 349.2 & 336.5 & -6.58 & -3.68 \\
\hline 9 & $2,041.6$ & $1,946.3$ & $1,845.3$ & -8.68 & -5.28 \\
\hline 10 & 595.5 & 572.3 & 545.3 & $=8.48$ & -4.78 \\
\hline U.S. Total & $21,187.2$ & $20,175.0$ & $18,971.6$ & -10.58 & -6.08 \\
\hline \multicolumn{6}{|c|}{ NONAGRICULTURAL } \\
\hline 1 & $5,286.8$ & $5,168.5$ & $4,975.1$ & -5.98 & -3.78 \\
\hline 2 & $9,975.5$ & $9,750.7$ & $\therefore, 354.0$ & -6.38 & -4.18 \\
\hline 3 & $10,306.5$ & $10,100.4$ & $9,726.7$ & -5.68 & -3.78 \\
\hline 4 & $14,692.7$ & $14,411.4$ & $13,922.0$ & -5.98 & -4.18 \\
\hline 5 & $19,297.3$ & $18,847.1$ & $18,160.8$ & -5.98 & -3.68 \\
\hline 6 & $9,637.6$ & $9,486.0$ & $9,201.2$ & -4.58 & -3.08 \\
\hline .7 & $4,964.5$ & $4,722.0$ & $4,625.0$ & -4.98 & -3.18 \\
\hline 8 & $2,936.8$ & $2,800.6$ & $2,724.8$ & -3.98 & -2.78 \\
\hline 9 & $11,299.3$ & $11,107.0$ & $10,769.0$ & -4.78 & -3.08 \\
\hline 10 & $3,136.5$ & $3,088.6$ & $2,999.5$ & -4.38 & -2.98 \\
\hline U.S. Tota & $91,333.5$ & $89,532.3$ & $86,358.2$ & -5.48 & -3.58 \\
\hline
\end{tabular}

\footnotetext{
* Region 1: Connecticut, Massachusetts," Maine, New Hampshire, Rhode Island, Vermont

Rèion 2: Néw Jersey, Néw Yurk

Region 3: Delaware, District of Columbia, Maryland, Pennsylvania, Virginia, West Virginia

Region 4: Alabama, Florida, Georgia, Kentucky, Mississippi, North Carolina, South Carolina, Tennessee

Region 5: Illinois, Indiana, Michigan, Minnesota, Ohio, wisconsin

Region 6: Arkansas, Louisiana, New Mexico, Oklahoma, Texas

Kegion \%: lowa, Kansas, Missouri, Nebraska

Region. 8: Colorado, Montana, North Dakota, South Dakota, Utah, Wyoming

Region 9: Arizona, California, Hawaii, Nevada

Region 10: Alaska, Idaho, Oregon, Washington

Source: Science Applications, Inc. Integrated Economic Assessment of Petroleum Supply Interruption Contingency Actions, october 1977.
} 


\section{PAGES 5.4 to 5.5 WERE INTENTIONALLY LEFT BLANK}




\subsection{INCREMENTAL STATE AND REGIONAL IMPACTS OF THE WEEKEND}

GASOLINE SALES RESTRICTIONS PLAN

5.2.1 Impacts on State Motor Fuel, Automotive and Highway Use Receipts

If refinery yields were changed to transform some of the "saved" gasoline to other refined products, state gasoline, tax receipts would 'decline. If all of the 204,000 BPD savings (formerly used by automobiles) were converted to other products. state gasoline revenues would decline by about $\$ 300$ million per year.

\subsubsection{State and Regional Economic Impacts}

The major determinant of the Weekend Gasoline Sales Restrictions plan on state and regional economies is the importance of the affected industries. Exhibit 5.2 displays information on the importance of tourism to state economies. In addition to being strongly impacted by an oil supply restriction, states with high percentages of travel-generated employment will be additionally damaged by weekend restrictions on gasoline sales.

5.6 
EXHIBIT 5.2 Relative Importance of Travel-Generated Tax Revenues

\begin{tabular}{|c|c|c|c|c|}
\hline & $\begin{array}{c}1976 \\
\text { Travel-generated } \\
\text { State } \\
\text { Tax Revenues } \\
\text { Millions } \\
\end{array}$ & $\begin{array}{c}\text { State Tax } \\
\text { Revenues } \\
\text { Millions } \\
\end{array}$ & $\begin{array}{r}\text { Percent } \\
\text { Taxes } \\
\text { By } \\
\end{array}$ & $\begin{array}{l}\text { of State } \\
\text { Generated } \\
\text { Travel }\end{array}$ \\
\hline Alabama & 51.1 & 1,111 & & 4.6 \\
\hline Alaska & 24.8 & 203 & . & 12.2 \\
\hline Arizona & 96.6 & 938 & & 10.3 \\
\hline Arkansas & 53.3 & 653 & & 8.2 \\
\hline California & $1,003.6$ & 9,565 & & 10.4 \\
\hline Colorado & 86.5 & 866 & & 10.0 \\
\hline Connecticut & 75.0 & 1,059 & & 7.1 \\
\hline Delaware & 8.7 & 336 & & 2.6 \\
\hline Florida & 441.1 & 2,791 & & 15.8 \\
\hline Georgia & 98.5 & 1,548 & & 6.4 \\
\hline Hawaii & 45.1 & 576 & & 7.8 \\
\hline Idaho & 25.3 & 298 & & 8.5 \\
\hline Illinois & 170.3 & 4,410 & & . 3.9 \\
\hline Indiana & 87.9 & 1,854 & & 4.7 \\
\hline Iowa & 42.2 & 1,062 & & 4.0 \\
\hline Kansas & 45.6 & 769 & & 5.9 \\
\hline Kentucky & 93.1 & 1,284 & & 7.3 \\
\hline Louisiana & 71.2 & 1,529 & & 4.7 \\
\hline Maine & 48.6 & 369 & & 13.2 \\
\hline Maryland & 86.5 & 1,731 & & 5.0 \\
\hline Massachusetts & 179.7 & 2,219 & & 8.1 \\
\hline Michigan & 187.8 & 3,486 & & 5.4 \\
\hline Minnesota & 159.9 & 2,022 & & 7.9 \\
\hline Mississippi & 55.7 & 797 & & 7.0 \\
\hline Missouri & 113.7 & 1,303 & & 8.7 \\
\hline Montana & 16.4 & 233 & & 7.0 \\
\hline Nebraska & 36.4 & 425 & & 8.6 \\
\hline Nevada & 53.7 & 267 & & 20.1 \\
\hline New Hampshire & 16.5 & 172 & & 9.6 \\
\hline New Jersey & 168.6 & 2,101 & & 8.0 \\
\hline New Mexico & 46.2 & 520 & & 8.9 \\
\hline New York & 347.3 & 8,939 & & $3 . \dot{9}$ \\
\hline North Carolina & 103.3 & 1,900 & & 5.4 \\
\hline North Dakota & 23.0 & 264 & & 8.7 \\
\hline Ohio & 147.9 & 3,039 & & 4.9 \\
\hline Oklahoma & 52.2 & 884 & & 5.9 \\
\hline Oregon & 38.0 & 793 & & .4 .8 \\
\hline Pennsylvania & 301.3 & 4,733 & & 6.4 \\
\hline Rhode Island & 14.1 & 350 & & 4.0 \\
\hline South Carolina & 82.5 & 9,51 & & 8.6 \\
\hline
\end{tabular}




\section{EXHIBIT 5.2 (Continued)}

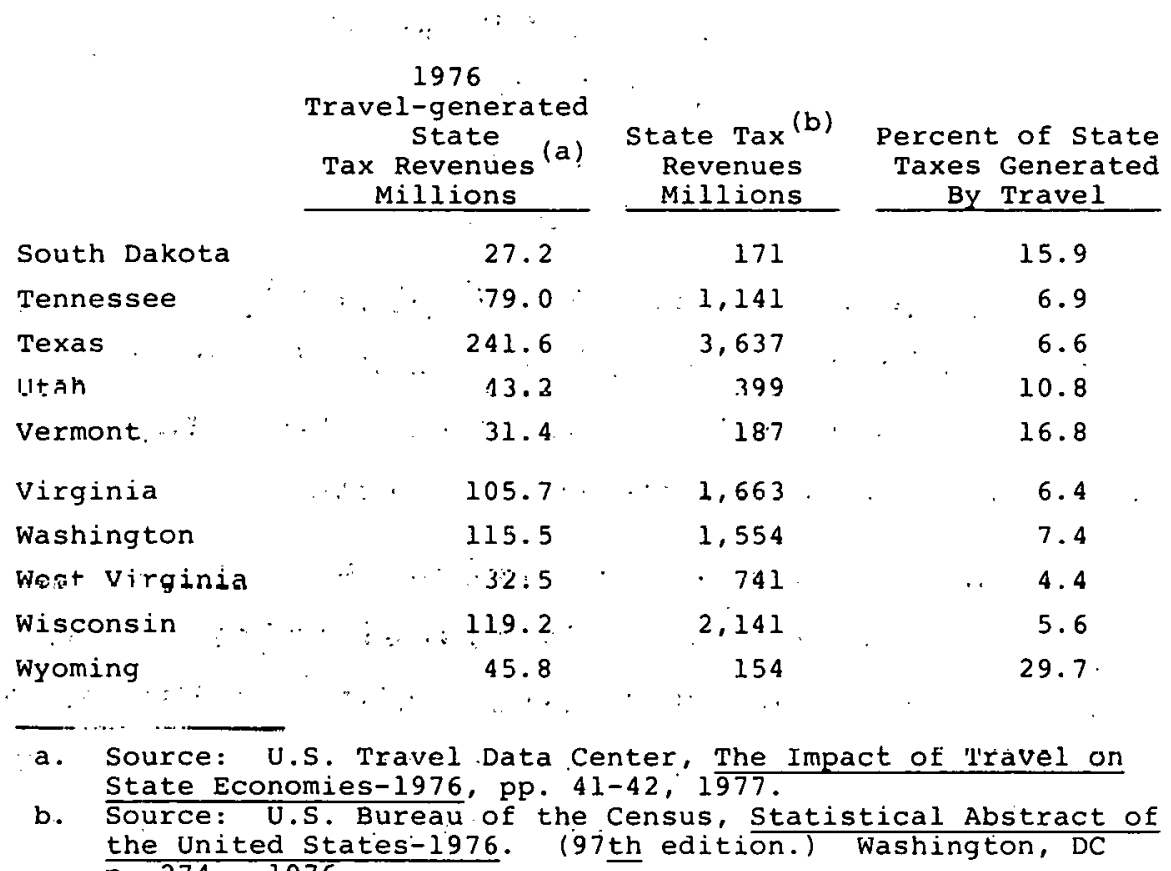


The states most dependent on tourism are:

- Nevada

- Hawaii

- Vermont

- Florida

- Wyoming
- Maine

- New Hampshire

- Minnesota

- Arizona

- Colorado

Several of these states (Hawaii and possibly Florida) generate relatively more of their tourism through air travel. A restriction on weekend automobile travel would be damaging but air travel and tours could absorb some of the losses.

Several areas can be identified which rely heavily on tourism and recreational industries. Historical sites of the East, ski areas in many states, and the resort areas of Nevada and New Jersey all depend on weekend visitors to contribute a substantial portion of their sales. Many of these areas are over 200 miles round trip from metropolitan areas; the plan would almost completely eliminate customers traveling by automobile.

Many of the states that depend on tourism for employment and sales revenue also depend on tourism for state tax receipts. Each dollar of travel spending generates an average 5.3 cents in state revenue of tax receipts. (3) Exhibit 5.3 shows U.S. travel generated state tax receipts, totally and as a percentage of total state taxes collected. States most likely to lose significantly depend heavily on travel generated taxes to support local public services. States generating 10 percent of state taxes from tourist travel are:

- Wyoming

- Nevada

- Vermont

- South Dakota

- Florida

- Maine
- Alaska

- Utah

- California

- Arizona

- Colorado

3. U.S. Travel Data Center, The Impact of Travel on State Economies 1976, N. 40, 1977 . 
The adverse impacts discussed above would be offset by benefits from using the conserved fuel. States most likely to benefit are those with significant proportions of total employment engaged in manufacturing and those hardest hit by the shortfall. As Exhibit 5.1 shows, the areas showing the greatest potential for employment gains would be in the Fast, South and Midwest. 


\subsection{FEDERAL COSTS}

It has been tentatively estimated that this plan could be implemented for nine months duration at a cost of about $\$ 5.2$ million. This represents $\$ 1.2$ million in direct Federal. costs (including 32 staff years of effort) and $\$ 4.0$ million in reimbursable costs to state and local government (including 170 staff years of effort). These estimates assume that this plan would be implemented alone. If, however, other standby conservation plans were in effect at the same time, operating economies could be achieved which would result in reduced overall costs. The estimates, which are very preliminary and are subject to budget review, include the cost of reimbursing the states for functions delegated to them.

It is contemplated that the Federal government would maintain a small staff to implement, administer and monitor this program. These personnel, located at headquarters and in the regional offices, would have designated responsibilities in the following areas:

- Program management and administration

- Exceptions and appeals

- Pubilic information

- Enforcement

It is DOE's intent, however, to delegate, to the extent possible, the enforcement and exceptions and appeals functions to State and local government. This approach has been selected for the following reasons: 
- The nature of the plan is such that State and local government may, with some relatively minor adjustments and by using such on-board personnel as building inspectors, police, etc., be prepared to conduct the inspections and investigations necessary to ensure compliance with this plan.

- State and local officials are aware of the special conditions and/or problems peculiar to specific areas or regions of the country. They are, therefore, in an excellent position to evaluate petitions for exceptions and appeals objectively and fairly.

- For this plan to be effective, a cooperative effort is necessary between all levels of government and the people of this Nation. Planning for meaningful participation of State and local government in this measure is an important way of coordinating Federal actions with the other levels of government and, in so doing, ensuring their cooperation. 
APPENDIX A

\section{DETAILED CALCULATIONS OF MAJOR INDUSTRY IMPACTS}

This appendix presents methods for calculating impacts to new automobile sales, the hotel-motel industry, campgrounds and trailer parks and, the restaurant industry.

\section{A. 1 NEW AUTOMOBILE SALES}

DRI Estimate of 1980-81 Automobile and Parts Retail Sales

$$
=\$ 99 \text { billion }
$$

Fraction of New Automobiles to New

Automobiles plus Parts

$$
=.60^{(2)}
$$

Projected New Auto Sales $=\$ 59.4$ billion

Sales after shortfail (3) $=\$ 46.3$ billion

Sàies Reduction Due to Plan (4) $=\$ 0.926$ billion

1. 1977 dollars. Data Resources, Inc., The Data Resources U.S. Long Term Review. Fall, 1977.

2. 1973 ratio. U.S. Bureau of the Census, Statistical Abstracts of the United States: 1976. (97th edition) Washington DC, 1976, p.791.

3. 22 percent reduction equal to that experienced in 1973-74.

4. Assumed 2 percont reduction. 


\section{A. 2 IMPACTS ON HOTEL-MOTEL INDUSTRY}

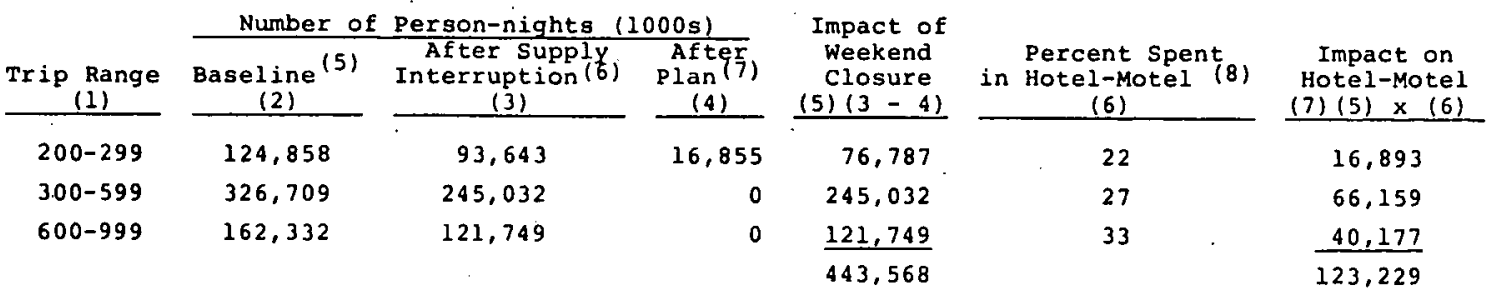

\footnotetext{
5. U.S. Travel Data Center, 1976 Natlonal Travel Survey. 1977, p. 55.

6. Assumed 25 percent reduction due to supply interruption (see section 4.3).

7. 200-299 mile trips are reduced by 82 percent, all others are eliminated.

8. These are the percentages for all travellers in these milage raines, not just weekend travellers. U.S. 'Iravel Data Center, 1976 National Travel Survcy. 1977 . p. 37.

Reduction.in Person-nights

Average per-person-night rate ${ }^{(9)}$

Gross loss of sales

Assume 25 percent offset $(10)$$$
=123,641,000
$$$$
=\$ 15
$$$$
=\$ 1,848 \text { million }
$$$$
=\$ 1,386 \text { million }
$$

\section{A. 3 IMPACT ON CAMPGROUNDS AND TRAILER PARKS}

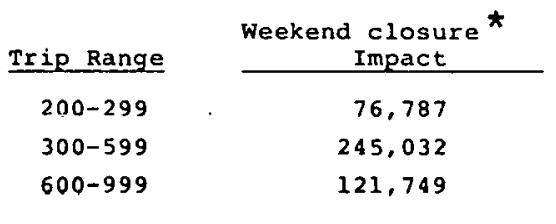

Person-nights $* *$
Spent in Category
34
21
17

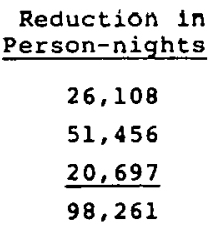

* $*$ From "Impacts on HOTEL-MOTEL Industry".

U.S. Travel Data Center, 1976 National Travel Survey, p.37,1977.

9. Laventhol and Horwath, "Trend of Business in The Lodging Industry", Philadelphia, PA, Nov. 1977, provides a $\$ 25 /$ night average for motels. The average number of persons per occupied room in 1976 was 1.70 , from the 1976 National Travel Survey, p. 10 .

10. A 25 percent offset due to substitution toward weekend trips and shorter trips. In addition it is expected hotels and motels would actively promote weekend business. 
Reduction in person-nights

Average fee per person-night

$\mathrm{x} \quad 1.50$

$\$ 147,391,000$

Dollar loss to Campgrounds is roughly $\$ 147$ million.

After 20 percent offset due to substitution to weekday trips and shorter for longer trips $=\$ 118$ million

\section{A. 4 IMPACT ON RESTAURANT INDUSTRY}

(a) Number of person-days on weekend auto trips (1976)

(b) Number of person-days on weekend auto trips (1981) (12)

(c) Reduction in person-days in plan ${ }^{(13)}$

$=938$ million

(d) Gross reductions in food expenditures on trips (1977\$)

$=822$ million

$=493$ million

(e) Gross reduction in restaurant revenues from auto travellers

$=\$ 4.14$ billion

(f) Gross reductions in total consumer expenditures on food (16)

$=\$ 2.29$ billion

11. The number is calculated by dividing total food expenditures on weekend automobile trips $(200$ roundtrip miles or more) by average food expenditure per person-day as shown in the 1976 National Travel Expenditure Survey (U.S. Travel Data Center, Washington, D.C.).

12. Assume 4\% growth from 1976-1981 and 28\% reduction from the shortfall.

13. All person-days on auto trips greater than 300 miles are eliminated. Seventy-two percent of person-day on trips between 200-300 miles are curtailed (see Section 4.4.2). Offset due to shorter and weekday trips is assumed to be forty percent (see gasoline consumption offsets in Exhibit 2.6).

14. Assume $\$ 10.50 /$ person-day on food expenditures. SOURCE: 1976 National Travel Expenditure Survey 
(g) Net reduction in total restaurant revenues $(17)$

$=3.68$ billion

(h) Net reductions in total consumer

expenditures on food $(1 \overline{8})$

$=2.04$ billion

A. 5 IMPACT ON EXPENDITURES FOR ENTERTAINMENT AND INCIDENTALS

(a) Reduction in person-days on auto trips from plan(19)

$=450$ million

(b) Expenditures on entertainment per person-day (1977\$) (20)

$=2.14$ billion

(c) Total expenditure reduction (a) $x$ (b) $=1050$ million

(d) Expenditures on incidental per person-

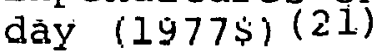

$=4.00 \mathrm{villioil}$

(e) Assumed fraction related to trips

(Souvenirs, suntan lotion, etc)

$=.20$

(f) Total expenditure reduction on

incidentals

$=400 \mathrm{million}$

15. Assume $80 \%$ of food expenditures on trips is in eating establishments.

16. Consumers are assumed to purchase the same quantity of food (valued at the wholesale level) whether they are on a trip or stay at home. According to the National Restaurant Association (NRA Washington Report, July 18, 1977), 1975 food service industry sales totaled $\$ 71.0$ billion and food and beverage purchasers by all food service establishments were $\$ 31.6$ billion. This implies an average margin of 125\%: This margin has been applied to the 1981 reduction in restaurant sales.

17. Per capita daily expenditures at commercial food service establishments was $\$ .93$ in 1977. It is assumed that each potential traveler continues to spend this average at restaurants and other eating places for each trip-day curtailed. Thus, the offset is (c) $x .93=\$ .46$ billion.

18. Subtract $.55^{\circ} \times \$ 46$ billion to (f).

19. See Section A.4.

20. U.S. Travel Data Center, 1976 National Travel Expenditure Survey, Table $8, \mathrm{p} . \dot{\mathrm{A}}-15$.

21. Ibid. 